\title{
From Conquest to Cognition: 20th Century Exploration Narratives RICHARD C. DAVIS'
}

Let us probe the silent places, let us seek what luck betide us; Let us journey to a lonely land I know.

There's a whisper on the night-wind, there's a star agleam to guide us, And the Wild is calling, calling ... let us go.

So wrote Robert Service, bard of the North, in 1907. Although the allure of distant horizons has changed since bold adventurers like Alexander Mackenzie, David Thompson, and Samuel Hearne crossed this vast continent, the mapping of the final scrap of terra incognita clearly has not silenced the wilderness call. Modern accounts of journeys "North of $60^{\circ}$ " illustrate that only the focus has shifted. As the topography becomes known, the emphasis falls away from objective descriptions of route and landscape and toward a personal response to the country traversed. Consider, for example, two "voyages of discovery" down the Mackenzie River. The first is by Mackenzie himself in 1789; his narrative of that trip records temperatures, distances, paces around rapids, parallels of latitude and longitude. Nearly two centuries later, Robert Mead follows in the wake of Mackenzie's canoe, but his story of that journey, Ultimate North, tells us little about the river itself. We learn instead of the effect it has on the traveller - of his fear as the river's current grips the canoe and speeds it toward torrential whitewater, of his love for his family, of his crisis when he realizes that he is a less skilled woodsman than he had thought. Wilderness exploration continues in our own century, but the object of the quest is far less tangible than the new lands that lured Mackenzie and other early figures into the elemental distances of green and blue.

Some of the most interesting developments in exploration literature have occurred since 1900 . Nearly all overland investigations of the Canadian mainland were financed in past centuries either by the Hudson's Bay Company or the Northwest Company. With the decline in the fur trade, this commercial incentive to search out new lands waned, allowing a broader spectrum of individualized motives to surface. The 20th century has witnessed a gradual evolution in the response to this "call of the wild," an evolution that moves through three phases. The first stage, occurring before the 1914-1918 War, is characterized by a desire to dominate the wilderness, to assert the unquestioned supremacy of the human will over undomesticated nature. Midway through the century, the travellers of the second stage sought a relatively simple enjoyment of the natural world, a realm offering both unlimited freedom and adventure and an escape from social confinement. In the past twenty years - the third and most recent stage - the explorer seeks out unspoiled regions for what he can learn from them, for the wilderness teaches him about himself and his antecedents. Three representative travels in the North sharply illustrate this development.

In Dillon Wallace's account of an expedition into the heart of Labrador in 1903, we can see that the driving spirit behind the undertaking was one of spartan conquest and willful determination. Urged on by the desire to "open up some really new territory" - as the expedition's leader, Leonidas Hubbard, phrased it - three men plunged into the rugged, uninviting interior of the peninsula. The area west of Northwest River Post had been crossed only twice other than by Indians, and like those wandering bands of natives, neither previous traveller had left any record. Accordingly, as Wallace tells in The Lure of the Labrador Wild, Hubbard planned to map this area, a region of such impenetrable terrain that it remained uncharted although it lay only 600 miles from Halifax. Such an opportunity could lead to the realization of Hubbard's dreams, as Wallace relates to us:

Here, then, was an enterprise fully worthy of an ambitious and venturesome spirit like Hubbard. Here was a great, unknown wilderness into which even the half-breed native trappers who lived on the outskirts were afraid to penetrate, knowing that the wandering bands of Indians who occasionally traversed its fastnessess themselves frequently starved to death in that inhospitable, barren country. There was danger to be faced and good "copy" to be obtained.

And so it was ho for the land of "bared boughs and grieving winds!"

Hubbard's expedition - and I carefully choose the word "expedition" for the quasi-military cast it lends to the undertaking - proposed to journey up Grand Lake to the mouth of the Naskaupi Riyer. After following the Naskaupi to Lake Michikamau, they would carry to the headwaters of the George River and float down to Ungava Bay, where they could secure passage back to civilization. Little of the plan was ever realized. Not fully under way until mid-July, they hurried to the far end of Grand Lake and entered the first river they saw, believing it to be the Naskaupi. A. P. Low's survey map of southern Labrador, the map on which Hubbard relied, tentatively sketched a single watershed - the Naskaupi - flowing into this part of the lake. In fact, five rivers empty in here. In their haste, Hubbard's group unwittingly passed by the Naskaupi's mouth and entered what is perhaps the least navigable of all - the Susan Brook.

Practically speaking, the Susan is unnavigable, but spurred on by a desire to test themselves against all but impossible hardship, to confront and tame the wilderness, 
Hubbard's men persevered. Amidst swarms of mosquitoes and bulldog flies, they pushed, dragged, shoved, and carried their heavily-laden canoe up the steep and narrow valley, portaging far more than they paddled, splashing fully-clothed through chill waters or plunging into the thick scrub of Labrador's forests. They often covered less than three miles in a day of torturous and brutal travel. The summer equinox behind them, the party felt the days grow shorter and the nights colder. Food supplies quickly proved inadequate for their severely restricted pace, and game, on which they had depended as an additional food source, seemed to have abandoned the region. Only one caribou was killed; small trout and an occasional ptarmigan were all the land offered, and even these were few. A giil-net would most certainly have provided fish, but as none were available at the post, Hubbard left without this essential piece of equipment, demonstrating a characteristic mixture of good faith in the reward of hard labor and an unflinching spartan indifference to adversity. It was as if this further deprivation would make the undertaking more significant. His determination to dominate the wild landscape by forcing his way through it became obsessive, as one can see in Wallace's assessment after six weeks of travel:

The situation that confronted us was serious. Hubbard had recently had another attack of diarrhoea, and was weak. The patches we put on our moccasins would last only a day or two, and we were practically barefoot. Our rags were hanging in strips. Our venison was going rapidly, and our flour was practically gone. To portage across country meant that we should probably not have many opportunities for fishing . . . Getting game had proved uncertain. Even were we to face towards home, we had not sufficient provisions to carry us half way to Northwest River Post.

That Thursday evening in camp we discussed the situation from all sides. We knew that if we pressed on winter in all probability would overtake us before we reached a post, but we decided that we should fight our way on to Lake Michikamau and George River. There was no doubt about it, we were taking a long chance; nevertheless, we refused to entertain the thought of turning back. Daring starvation, we should on the morrow start overland and see what lay beyond the hills to the northward. "Michikamau or Bust!" was still our slogan.

Throughout the first half of the narrative, these travellers repeatedly meet extremes of deprivation unyieldingly. The reader wants constantly to cry out "Go back, you fools! Go back!" as they persistently force their way into even harsher circumstances. Their hardened determination becomes a source of both fascination and repulsion, carrying the reader spellbound through to the shore of Windbound Lake where, finally within sight of Michikamau but imprisoned by a relentless wind, Hubbard's party must give it up.

The decision is a difficult one to make. Nevertheless, once Hubbard acknowledges himself "defeated in his purpose," the party thinks of nothing but how to reach home most quickly. The book's second half tells of this desperate retreat, a struggle which alternately encourages and frustrates them. Elson alone reaches Northwest River
Post without help. A rescue party finds Wallace weak but alive beside the Susan Brook; they discover Hubbard's frozen body inside his snow-rimed tent.

The response here is clear. Although Hubbard seeks out the wilderness - even loves it with a romantic passion he is driven to tame it. He wishes to dominate it, to put it on a map, to assign names to its lakes and rivers and mountains. His response brings to mind the giants of the past - men like Mackenzie and Thompson and Hearne, for they too sought to bring light into the darkness, to transfer the mystery of the unknown to a two-dimensional map surface. Yet one cannot seriously compare Hubbard's "work" - as he constantly referred to it - with the search for faster trade routes and richer furs that motivated his predecessors. Simply, Hubbard had been born too late for this sort of discovery. All of the major river systems had been charted; Hubbard could only participate in the spirit of these explorations by plunging into the barren and harsh interior of the Labrador, a region that aroused little curiosity in either the public or the scientific mind. His trip had little to do with objective purpose, but like most wilderness travellers of this century, he was driven by a far more introspective quest.

Nevertheless, much of the same force that impelled Hubbard to the extremes he relished drove several generations of rigorous outdoorsmen, men powerfully influenced by the late-Victorian era. The stoicism, the self-willed tenacity to complete an assigned task is a part of the unsparing ethos of adventure that grew out of an imperialistic philosophy. In Pax Britannica, James Morris sketches the late 19th century character that would have been the standard of behaviour for Hubbard, born in 1872:

Much of the driving force of imperialism, as of Victorian progress in general, was the energy sparked by man's struggle with his own environment, and to many of the imperialists the struggle was an end in itself. The notion of a perpetual striving was essential to the morality of the day ... A puritanical pleasure in hardship was often allied with a boyish delight in rip-roar, the two formidably combining to produce a breed of stoic adventurers, for whom the imperial mission was a larger embodiment of a personal challenge. These instincts were, of course, strongly reinforced by the training of the public schools, with their emphasis on spartan endurance.

Hubbard's enterprise was truly meaningful only to the individuals involved. However, because the imperialist ethos to which they were in thrall gave slim recognition to what might be construed as frivolous recreation - that is, activity without material accomplishment - Hubbard set the task of adding to the stores of geographical knowledge. His travels embody the transition between centuries. Straddling the year 1900 , he has one foot in that same powerful mold that formed the unflinching Sir John Franklin, the other solidly implanted in the 20th century, a period offering few chances to discover new lands.

But where the North is in question, the turn of the century is a nearly insignificant demarcation between cultural attitudes; the most remarkable impact came from 
the 1914-1918 War. The science of aviation, developed in support of the war effort, virtually rendered both the wilderness and the explorer - at least in the context that the 19th Century had known them - obsolete, curiosities of an earlier age. Yet certainly man's spirit to explore did not disappear along with the terra incognita, and if we look at a post-war narrative, a marked difference in the response to that northern call can be seen.

R. M. Patterson's The Dangerous River is typical of these later accounts. Revelling self-indulgently in the pleasures he finds in the hinterlands, he celebrates the personal freedom of unrestricted wandering and the excitement of unsupervised outdoor adventure. Unlike Hubbard, who was driven to subdue the Labrador, Patterson only wants to enjoy the wild country before it is overrun with other pleasure-seekers. During the summer of 1927 he paddled, poled, and tracked his sixteen-foot Chestnut canoe up the legendary South Nahanni River. Situated where the borders of British Columbia, the Yukon, and the Northwest Territories meet, the Nahanni flows out of the Mackenzie Mountains and into the Liard River. Patterson spent the warm months working his way upriver to the foot of Virginia Falls, a magnificent cataract guarding the river's upper stretches. With the approach of autumn, he left the Nahanni to winter in Edmonton with a friend, George Matthews, but both men returned to the Nahanni in the following spring, outfitted to spend the entire year. The cabin they built on the banks of Flat Creek served as a winter base from which they ranged freely throughout the valley until the end of the next summer.

We have seen the pragmatic objective that Hubbard held in front of his own nose as one holds a wisp of hay before a donkey. Patterson also had a practical goal in mind when he left for the Nahanni: his search was not for land, but for gold. It is worthy of notice how readily he gives up this purposeful design once he finds himself deep in the silent realm of woods and waters, where his favor falls instead on a myriad of unexpected delights that could not have been anticipated beforehand. In his Foreword, he writes:

This book is the story of the Nahanni country and of an attempt to find the lost gold of that little-known land. The attempt failed, so this must also be a story of a failure - but it was a failure that succeeded in so many other ways that, if life could be entirely filled with such defeats, I for one would never ask for any victory.

His attitude is easily distinguished from Hubbard's. Before Hubbard had ever seen the Labrador peninsula, he set rigid and rigorous goals for himself; what followed was really a matter of human will, to which the wilderness acted merely as an obstruction. On the other hand, Patterson's plans change to accommodate the pleasures and hazards that arise at the immediate moment. He responds to the wilderness as a source of freedom, as a locale immune to the restrictions of social confinement. Hub- bard's effort was to overcome the wilderness, but Patterson wants only to enjoy it.

Although The Dangerous River does not recount a gruelling struggle against the primal world, do not assume that Patterson prefers simple security to adventure. Sharply alert to the satisfaction that comes from meeting physical challenges, he differs from Hubbard in this respect only in the degree of suffering and hardship he will tolerate. In addition, he is considerably more skilled at distinguishing between stimulating excitement and simple foolhardiness; as a result, his experiences are positive and his response bears little in common with Wallace's dark expressions. For example, he describes crossing a snow bridge in February over an open stretch of the bone-chilling Nahanni. Immediately after he reaches the opposite shore, the bridge collapses into the frigid torrent, but Patterson can remark on his delight with the experience. Almost flippantly, he observes: "I put the line away into the packsack with the feeling of satisfaction that only comes from taking a calculated risk and getting away with it." Had that risk been more heroic than calculated, Patterson's tone might have been more like Wallace's brooding description of the Susan Valley as "the Valley of the Shadow of Death." But Patterson's fun has nothing to do with needless hardship or the realization of predetermined goals; consequently, his narrative can remain light in tone.

Whatever misadventures occur cause only minor delays and inconveniences - not disasters. The hazardous encounters are, as Patterson says, "calculated risks." He turns to the woods for pleasure, avoiding any challenge that could lead to severe discomforts should the attempt fail. Whenever the peril of an adventure appears unduly harsh, the situation can always be circumvented and the game postponed until the odds improve, a freedom of action that holds much of the wilderness allure for Patterson. Clearly, he views these challenges as "games," not as desperate bids for survival, as his account of a rivercrossing shows:

We portaged everything except the canoes, poles and paddles; and when that was done we sat down in the bay where our stuff was and cooked and ate a tremendous meal, "because if we make a mess of that crossing it'll be a long, cold day before we see grub again - if we ever do." And then we walked back to the canoes - which, incidentally, we could have portaged too, like the rest of the stuff, but what fun was there in that?

The free-ranging outdoor life offers too great a potential for good fun to warrant seriously risking it all in the name of self-styled heroism. Characteristically, where Hubbard had thought of his expedition as "work," Patterson unashamedly states: "We travelled because we liked the life."

Not only does he approach these personal challenges in a different frame of mind, but his treatment of other wilderness features is similarly distinct. Wallace describes the Labrador flies as "villainous, hellish . . . They got into our nostrils, into our ears, into our mouths, into our eyes 
even, and our faces and hands were streaked with blood from their bites." This additional "nightmare" of exploration puts another feather in the cap of anyone heroic enough to persevere in its face. But the swarms of insects encountered by Patterson are the subject of the traveller's dry wit; he complains about them, but not without a certain acceptance. Consider the tone with which he speaks of them here:

This was the day of the new hatch of mosquitoes, and several thousand of these keen young sap-suckers were actively on the job, experimenting with human blood and evidently quite enjoying it. The big, old mosquitoes that Nature so wrong-headedly nurses through the winter to prevent the extinction of the race are deliberate even to the point of fussiness. One can deal with them as they stroll about on the back of the hand, searching for some dainty tidbit. But the illimitable hordes of June are in a hurry: they land with all the fury of youth and where they land they drill, in a second, through the toughest hide: death means nothing to them - it merely makes room for more.

Here we have no spartan conqueror, but a man who, if he cannot love the wilderness in all its guises, at least tolerates it. Unable to enjoy every back-country experience, Patterson at least takes pleasure with his wry, verbal response to all of them.

Another mid-century traveller of this second phase, P. G. Downes, comes to mind here. His book Sleeping Island tells of a summer-long canoe trip in the North. Beginning at Pelican Narrows, Saskatchewan, his journey follows the waterways north to Nueltin Lake on the edge of the Barren Lands, and distinct as this topography is from the South Nahanni River, Downes's attitude toward his environment is remarkably like Patterson's. I wish only to point out a remark Downes makes on his return to civilization. Flying back over Pelican Narrows at the close of his holidays, he comments:

Once more I saw from the air Pelican and all it had always stood for: happiness, friendship, the stepping stone to freedom and adventure, the first portage to the North.

"The stepping stone to freedom and adventure, the first portage to the North" - this fragment from Sleeping Island could well serve as a slogan for all the mid-century voyageurs, for it voices the primary magnetisms that the wilderness holds for them. Freedom and adventure - the refined essence of what draws Patterson and Downes ever northward.

One senses that when these men have completed their roamings - when canoes are tucked away securely above the rafters of suburban garages and the comfort of supple moccasins is sacrificed to the more stylish oxford - then they step back into their civilized roles, refreshed, rested, and rich with bucolic memories and exciting stories. But there is no suggestion that they actually have been changed by their experiences. Like schoolboys at recess, they have been too hard at play to concern themselves with mental or emotional development. Such matters can wait until the holiday is finished, or to complete the schoolboy analogy, until the bell rings and classes resume.
However, in the narratives of most recent journeys, those making up the third phase in this changing response to the wilderness call, the distinction between playground and classroom is not so clearly marked. If anything, the emphasis is on the classroom, on learning - particularly on learning about the self. I mentioned Robert Mead's Ultimate North, comparing it to Mackenzie's 18th century account of exploring the arctic-flowing river that bears his name. Following in the wake of that intrepid Scot, Mead and his son pushed off from shore on a drizzling day in the first week of June, 1974. Their voyage of discovery would carry them from Fort McMurray down the Athabasca, Slave, and Mackenzie Rivers to the frigid saltwater of the Beaufort Sea. The seventeen-hundred-mile canoe trip strongly affects Mead's personality - he will not go back to Philadelphia an unchanged man. Previous to heading North, he had a dream which prophesied a new life:

Somewhere in the weeks before we left I had dreamed of our departure: a steep rocky bank, at the bottom a big river boiling in torrent, the canoe loaded and waiting, a crowd of people behind us and no choice but to attempt what is beyond us; we step in, push off, are dumped, all lost. I do not dream much and take the dreams all the more seriously for their rarity. I would be watching for that particular configuration of flowing water and solid ground, would know it when we came to it. For those in life, death is a symbol, meaning transformation. We could not make this trip, my son and 1 , without much change.

This symbolic death allows for a psychic rebirth, and Mead's sensibility - his readiness to respond to emotional and psychological as well as physical experiences transforms his descent of the vast, mud-brown Mackenzie into an exploration deep within his own consciousness.

This change - this psychic rebirth - is brought about by what Mead learns on his journey. Phrases such as "We were learning," "Further instruction," and "The Delta had reserved a lesson for us" become catchphrases preparing the reader for the discoveries that Mead will make about himself. Consider, for example, the realization he makes upon reaching Fort Chipewyan:

Above all, it seemed, I needed to be among people again. It was another small discovery about myself. One way or another, my life has insulated me against the human herding instinct, gladly, on the whole; a writer's work is necessarily done in solitude. Now, the week on a river whose people had departed had shifted the balance - and I needed them after all ... I needed to be with other people.

Patterson cannot take back the intense excitement of shooting rapids, but this self-discovery that Mead achieves will remain with him throughout his life. Nor is it a realization that he could have won previous to the trip, although he was nearly fifty when he embarked. It is Mead's response to the elemental world of canoe and river that creates this epiphany for him now.

In fact, the extent to which Mead carries this selfanalysis is, at times, a source of uneasiness to the reader. One feels one is being made privy to secrets that should remain known only to Mead, as he expresses his fears, 
frustrations, and hopes with an almost confessional honesty. Here, he painfully elaborates on his own failings as he and his son reach a campsite after an exhausting day:

We unloaded, pulled the canoe out . . I lay down, too tired to move. But we still had to eat something. I found a can of beans, emergency food, as yet untouched, the little gasoline stove we carried for the same purpose it was too dark to find wood, I was too exhausted to collect rocks for a fireplace, build a fire. But I could not seem to get the stove to light; or the jet sputtered with a smoky flame feeble as a candle. I took it apart, cleaned it, emptied the tank and refilled it; nothing. I became more and more depressed, and the feeling doubled back: self-disgust that so small a thing could bother me so much. Drop me anywhere in the wilderness, I had boasted, with a knife and a box of matches and I'll manage, I'll survive and get out again. Perhaps; yet now that self-reliance seemed contemptible, as if all my life I had depended not on myself but on things, a series of tiny defences against no longer having a choice, one more thing that I could do to postpone failure and despair. I had worshipped them as truly as a savage the magic carried in a pouch at his breast, and when they failed me I was lost. And we were still only at the beginning of the trip, the sixth day out $\rightarrow$ the easiest part . .

We ate the beans cold, out of the can.

Nothing like this appears in any of the records of earlier travellers. Mead's wilderness has been surveyed, photographed, and charted too often to warrant yet another objective description; what we get instead is a map, so to speak, of the traveller's consciousness.

In contrast to Hubbard's spartan penetration of uncharted regions and Patterson's impulsive rangings through the Nahanni Valley, Mead deliberately chooses to follow closely in the wake of a previous explorer, a choice that further suggests his search for identity. But here awareness of his cultural antecedents counts for more than simple knowledge of his own individual depths and limitations. The book's subtitle - Canoeing Mackenzie's Great River - emphasizes the discoverer of the river by using the possessive ending, rather than the more conventional form of "the Mackenzie River." The history of the watercourse is as important to Mead as is the river itself, the inevitable result, one supposes, of a shrinking Canadian wilderness. Mead hypothesizes: "If you could reexperience that voyage of discovery, follow that route with his informed eyes, perhaps you could enter into his time as well. Romantic? An escape from a threatening present? And yet - "Where Patterson had celebrated the immediacy of the moment as a highlight of wilderness living, Mead attempts to transcend his own time and reach back into the time of Mackenzie, for through his identification with this heroic figure of the past, Mead can more clearly understand his own self.

Spartan testing center, unrestricted playground, medium for self-discovery - whatever it is that the 20th century traveller sees when he looks to those northern distances, he unmistakably hears that same "whisper on the night-wind" that beckoned to Service. It would be wrongheaded to insist that every modern explorer falls into one of these three chronological stages. But this framework should serve as a useful guide, enabling us to better appreciate the driving force behind such other excellent tales of wilderness travel as Douglas's Lands Forlorn, Camsell's Son of the North, Patterson's Finlay's River and Trail to the Interior, Rowland's Cache Lake Country, and Olson's The Lonely Land. Whether conquest and domination, freedom and adventure, or personal and cultural identity are the objects of the northern quest in this century, the completed topographic survey of the Canadian mainland clearly did not silence that wilderness call. The distant horizons that lured that bold breed of explorers of the past are today interior horizons, as each individual, still drawn by the "call of the wild," must find his own answer to the question a contemporary poet raises:

\section{So you should have travelled with them. Or with La Salle. He could feed his heart with the heart of a continent, Insatiate, how noble a wounded animal, \\ Who sought for his wounds the balsam of adventure, \\ The sap from some deep, secret tree. But now \\ that the forests are cut down, the rivers charted, \\ Where can you turn, where can you travel?}

Douglas Le Pan/"Coureurs de Bois"'

\section{BIBLIOGRAPHIC REFERENCES}

DOWNES, P.G. 1943. Sleeping Island: The Story of One Man's Travels in the Great Barren Lands of the Canadian North. New York: Coward-McCann, Inc. $296 \mathrm{p}$.

LE PAN, DOUGLAS. 1948. The Wounded Prince and Other Poems. London: Chatto and Windus. $39 \mathrm{p}$.

MEAD, ROBERT DOUGLAS. 1976. Ultimate North: Canoeing Mackenzie's Great River. Garden City, New York: Doubleday and Company, Inc. $312 \mathrm{p}$.

MORRIS, JAMES. 1978. Pax Britannica: The Climax of an Empire. London: Faber and Faber.

PATTERSON, R.M. 1954. The Dangerous River. Rpt. 1966. Sidney, B.C.: Gray's Publishing Ltd. 272 p.

SERVICE, ROBERT. 1945. "The Call of the Wild." In: The Complete Poems of Robert Service. New York: Dodd, Mead \& Company.

WALLACE, DILLON. 1905. The Lure of the Labrador Wild: The Story of the Exploring Expedition Conducted by Leonidas Hubbard, Jr. 7th ed. New York: Fleming H. Revell Company.

\section{FURTHER READING}

CAMSELL, CHARLES. 1954. Son of the North. Toronto: The Ryerson Press. 244 p.

DOUGLAS, GEORGE MELLIS. 1914. Lands Forlorn: A Story of an Expedition to Hearne's Coppermine River. New York: G.P. Putnam's Sons. $285 \mathrm{p}$.

PATTERSON, R.M. 1968. Finlay's River. Toronto: Macmillan of Canada. $315 \mathrm{p}$.

1966. Trail to the Interior. New York: William Morrow and Company, Inc.

ROWLANDS, JOHN J. 1947. Cache Lake Country: Life in the North Woods. New York: W. W. Norton and Company Inc.

SETON, ERNEST THOMPSON. 1911. The Arctic Prairies: A CanoeJourney of 2000 Miles in Search of the Caribou. Rpt. 1943. New York: International University Press. 308 p.

WALLACE, DILLON. 1907. The Long Labrador Trail. New York: The Outing Publishing Company. 